Kebijakan: Jurnal Ilmu Administrasi

Volume 10, Nomor 1, Januari 2019

E-ISSN: 2656-2820

P-ISSN 1829-5762

\title{
STRATEGI KOMUNIKATOR DALAM MENINGKATKAN KUALITAS PELAYANAN PELANGGAN AIR MINUM PDAM KOTA SUKABUMI
}

\author{
Ike Rachmawati \\ Fakultas Ilmu Sosial dan Ilmu Politik, Univeritas Muhammadiyah Sukabumi \\ Sukabumi, Jawa Barat, Indonesia \\ ike_rachmawatil@yahoo.com
}

\begin{abstract}
ABSTRAK
Penelitian ini berangkat dari fenomena di PDAM Kota Sukabumi yang berkaitan dengan keluhan pelanggan terhadap pelayanan pelanngan air minum yang dirasakan belum optimal. Penelitian yang dilakukan untuk menguji secara empirik fakta -fakta yang terjadi di lapangan serta menguji secara ilmiah variable penelitian strategi komunikator dan kualitas pelayanan. Penelitian dilaksanakan dengan menggunakan desain kuantitatif dengan metode explanatory survey, yakni: menjelaskan dan menganalisis Strategi Strategi komunikator yang mampu meningkatkan Kualitas Pelayanan Perusahaan Daerah Air Minum Kota Sukabumi, baik secara parsial maupun secara simultan. Pertimbangan mendasar penelitian ini dilakukan dengan desain kuantitatif, karena: (1) ingin mencari pengaruh antar variabel X dengan variabel Y; (2) Variabel X (Peran Strategi komunikator) dan variabel Y (Kualitas Pelayanan) dapat diukur secara kuantitatif berdasarkan indikator-indikator dari masing-masing dimensi dengan menggunakan statistik terapan; (3) Mengajukan hipotesis atau jawaban sementara atas pertanyaan penelitian sebagai acuan dalam mengumpulkan data empiris atau verifikasi data di lapangan, sesuai dengan maksud dan tujuan penelitian. Populasi dalam penelitian ini adalah pelanggan Perusahaan Daerah Air Minum Kota Sukabumi. Sampel yang digunakan adalah masyarakan yang merupakan pelanggan Perusahaan Daerah Air Minum Kota Sukabumi. Teknik sampling yang peneliti gunakan adalah simple random sampling.
\end{abstract}

Kata Kunci: Strategi, Komunikator, Kualitas Pelayanan, Pelanggan.
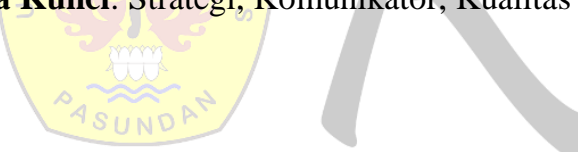

\section{ABSTRACT}

This research departs from a phenomenon in PDAM Sukabumi City related to customer complaints about drinking water customer services that are not yet optimal. The research was conducted to test empirically the facts that occurred in the field and scientifically test the research variables of communicator strategies and service quality. The research was carried out using a quantitative design with an explanatory survey method, namely: explaining and analyzing the strategies of communicators that are able to improve the service quality of the Regional Drinking Water Company in Sukabumi City, either partially or simultaneously. The basic consideration of this research is carried out with a quantitative design, because: (1) want to find the influence between variable X and variable $Y$; (2) Variable X (role of communicator strategy) and variable $Y$ (Quality of Service) can be measured quantitatively based on the indicators of each dimension using applied statistics; (3) Proposing hypotheses or temporary answers to research questions as a reference in collecting empirical data or verifying data in the field, in accordance with the aims and objectives of the study. The population in this study were customers of the Regional Drinking Water Company in Sukabumi City. The sample used is the community who are customers of the Regional Drinking Water Company in the City of Sukabumi. The sampling technique that researchers used was simple random sampling.

Keywords: Strategy, Communicators, Service Quality, Customers.

\section{PENDAHULUAN}

Menimbang Undang-Undang Nomor 23 tahun 2014 tentang Pemerintahan Daerah, disebutkan bahwa penyelenggaraan pemerintahan daerah sesuai dengan amanat Undang-Undang Dasar Negara Republik Indonesia Tahun 1945, diarahkan untuk mempercepat terwuj udnya kesejahteraan masyarakat melalui peningkatan pelayanan, pemberdayaan, dan peran serta masyarakat, serta peningkatan daya saing daerah dengan memperhatikan prinsip demokrasi, pemerataan, keadilan, 


\section{Kebijakan: Jurnal Ilmu Administrasi \\ Volume 10, Nomor 1, Januari 2019 \\ E-ISSN: 2656-2820 \\ P-ISSN 1829-5762}

keistimewaan dan kekhususan suatu daerah dalam sistem Negara Kesatuan Republik Indonesia. Dengan demikian, peningkatan pelayanan kepada masyarakat menjadi salah satu kriteria keberhasilan penyelenggaraan pemerintahan daerah. Pelayanan kepada masyarakat atau pelayanan publik dalam arti sempit adalah suatu tindakan pemberian barang dan jasa kepada masyarakat oleh pemerintah dalam rangka tanggung jawabnya kepada masyarakat, baik diberikan secara langsung maupun melalui kemitraan dengan swasta dan masyarakat. Konsep ini lebih menekankan bagaimana pelayanan publik berhasil diberikan melalui suatu "delivery system" yang sehat dengan tujuan untuk menyediakan barang dan jasa yang terbaik bagi masyarakat. Dari sekian banyak pelayanan publik yang dilakukan oleh pemerintah daerah, satu diantaranya adalah pelayanan yang merupakan hajat hidup orang banyak yaitu air yang dikelola oleh Perusahaan Daerah Air Minum disingkat PDAM. Pengelolaan air bersih merupakan hal yang sangat penting dan merupakan kebutuhan yang paling utama dalam memenuhi kebutuhan masyarakat sehari-hari. Dalam Undang-Undang Dasar 1945 Pasal 33 ayat 3 pun dijelaskan bahwa, Bumi dan air dan kekayaan alam yang terkandung di dalamnya dikuasai oleh negara dan dipergunakan untuk sebesar-besarnya kemakmuran rakyat.ll Pengelolaan air merupakan hal yang sangat penting dan merupakan tantangan yang utama untuk pembangunan masa depan. Selain fokus pada sumber air tidak berarti mengurangi perlunya menutupi sektor lain, akan tetapi justru perlu memadukan secara penuh perencanaan. Khususnya di bidang yang berhubungan dengan air seperti perumahan, pariwisata, industri.

PDAM berupaya untuk memperlancar proses pelayanan, namun masih sering dijumpai kendala-kendala dalam proses pelayanan yang berkenaan dengan kepastian waktu, biaya, maupun tenaga yang diperlukan. Berdasarkan pengamatan; dalam pelaksanaan pelayanan oleh PDAM, masyarakat merasakan masih banyak kelemahan yang diduga dapat menciptakan berbagai peluang penyimpangan, seperti mekanisme dan prosedur pelayanan yang panjang, tidak ada kepastian waktu penyelesaian dan biaya tinggi; kurangnya transparansi informasi, baik mengenai ketentuan, mekanisme prosedur, persyaratan maupun proses penyelesaiannya; dan kurang profesionalnya pelayanan yang diberikan oleh aparat. Berdasar Surat Keputusan (SK) Walikota Daerah Tingkat II Sukabumi No. 89/kpts/1966 merupakan Perusahaan Daerah Air Minum (PDAM) Tirta Bumi Wibawa Kota Sukabumi yaitu salah satu Badan Usaha Milik Daerah (BUMD) yang didirikan berdasarkan Peraturan Daerah No. 3/PD/1975. Pengaturan Perusahaan Daerah Air Minum (PDAM) Tirta Bumi Wibawa Kota Sukabumi diatur dengan Peraturan Daerah Nomor 5 Tahun 2002 tentang Perusahaan Daerah Air Minum (PDAM) Tirta Bumi Wibawa Kota Sukabumi dengan maksud dan tujuan antara lain:

1. Memberikan pelayanan air bersih;

2. Membantu dan mendorong pertumbuhan perekonomian daerah;

3. Sebagai salah satu sumber Pendapatan Asli Daerah (PAD) Kota Sukabumi.

Permasalahan seperti tersebut sehingga peneliti berasumsi karena pelayanan yang diberikan kepada pelanggan atau konsumen belum optimal atau belum memuaskan. Berdasarkan hasil wawancara dan observasi juga data yang diperoleh oleh peneliti, ditemukannya fenomena permasalahan di Bagian Hubungan Langganan Perusahaan PDAM Kota Sukabumi yang berhubungan dengan belum puasnya pelanggan terhadap pelayanan yang diberikan dengan indikasi sebagai berikut:

1. Pelanggan mengeluh bahwa tidak mendapatkan air, hal tersebut dapat dilihat ketika pelanggan ingin menggunakan air namun tidak sesuai dengan apa yang diharapkan pelanggan tersebut. Padahal pelanggan tersebut telah secara rutin membayar iuran setiap bulannya;

2. Pelanggan mengeluhkan bahwa sering bocornya pipa dinas yang tentunya mengganggu pelanggan dalam menggunakan air tersebut, karena dengan demikian air tersebut tidak dapat terdistribusikan atau tidak dapat dialirkan; 
3. Pelanggan mengeluhkan tentang air yang tidak layak digunakan, karena air dari PDAM Kota Sukabumi tersebut kotor, keruh, bau, sehingga tidak layak untuk dikonsumsi dan juga digunakan untuk mandi.

Fenomena tersebut di atas, tidak hanya mengidentifikasikan masih belum optimalnya kualitas pelayanan Perusahaan Daerah Air Minum (PDAM) Tirta Bumi Wibawa Kota Sukabumi, akan tetapi menggambarkan belum optimalnya fungsi komunikasi di lingkungan PDAM Kota Sukabumi. Hal ini sesuai dengan hasil penelitian tahap pertama yang menemukan bahwa ada pengaruh signifikan dari variabel Strategi komunikator terutama dalam dimensi Strategi komunikator. Hasil ini menunjukkan bahwa strategi komunikator memiliki peranan penting dalam meningkatkan kualitas pelayanan Air Minum PDAM Kota Sukabumi. Pelanggan menilai bahwa keterampilan teknis yang dimiliki oleh pegawai PDAM masih rendah, sehingga dalam memberikan pelayanan belum cepat tanggap dan pelanggan belum dapat informasi yang tepat dari pagawai PDAM. Hal ini menunjukkan bahwa bahwa pegawai sebagai strategi komunikator belum dapat melaksanakan fungsi komunikasinya dengan baik. Pesan yang disampaikan masih berbelit belit terutama dalam hal pengaduan pelanggan dan proses dokumen permohonan pelayanan air minum. Apabila kualitas pelayanan yang diberikan oleh PDAM Kota Sukabumi tidak ditingkatkan, maka akan menimbulkan citra negatif dan rendahnya tingkat kepercayaan publik kepada PDAM Kota Sukabumi.

Berdasarkan uraian dan hasil penelitian tahap pertama, maka peneliti tertarik untuk melakukan penelitian lanjutan tentang Strategi Strategi komunikator dalam Meningkatkan Kualitas Pelayanan di PDAM Kota Sukabumi yang merupakan salah satu instansi yang memberikan pelayanan vital berupa sumber kehidupan kepada masyarakat. Pelayanan pada masyarakat dikatakan baik apabila masyarakat sebagai konsumen mudah mendapatkan pelayanan dengan prosedur yang sederhana, biaya murah, waktu cepat, dan jarang ada keluhan yang dilontarkan masyarakat atau konsumen. Berdasarkan fenomena-fenomena yang diungkapkan dalam latar belakang penelitian, maka problem statement penelitian sebagai berikut: "Kualitas Pelayanan Pelanggan Air Minum PDAM Kota Sukabumi belum optimal, dikarenakan strategi komunikator yang dilakukan oleh strategi komunikator yang belum efektif." Berdasarkan problem statement, maka peneliti mengemukakan pertanyaan penelitian research question sebagai berikut: "Seberapa Besar Pengaruh Strategi Strategi komunikator terhadap Kualitas Pelayanan Pelanggan Air Minum PDAM Kota Sukabumi?"

\section{Komunikasi dan Administrasi Publik}

Istilah komunikasi (dalam bahasa Indonesia) atau communication (dalam bahasa Inggris) itu berasal dari bahasa Latin communicatio yang berarti pemberitahuan, pemberian bagian (dalam sesuatu), pertukaran, dimana si pembicara mengharapkan tanggapan atau jawaban dari pendengarnya; ikut mengambil bagian. Kata sifatnya communis artinya bersifat umum atau bersama-sama. Kata kerjanya communicate, artinya berdialog, berunding atau bermusyawarah (Arifin, 2006:19-20). Menurut Spacek \& Spalek (2007:3) bahwa:

In general, the term communication is defined as a transmission of information between two or among more subjects within certain time and certain place, or as a transmission of various information contents within various communication systems by the utilization of various communication media, particularly through language. Within the process of communication, it is important to answer the following questions: Who is the recipient of my information? What information does this recipient demand? What information may I/do I have to give him. Which way of the transmission does he or she prefer? What do I want to achieve by providing the recipient with the information? 


\section{Kebijakan: Jurnal Ilmu Administrasi \\ Volume 10, Nomor 1, Januari 2019 \\ E-ISSN: 2656-2820 \\ P-ISSN 1829-5762}

Memperhatikan pendapat di atas, bahwa dalam proses komunikasi, pertanyaan-pertanyaan berikut penting untuk dijawab, yaitu siapa penerima informasi? informasi apa yang diminta penerima? informasi apa yang bisa saya berikan? transmisi apakah yang disukai? dan apa yang ingin dicapai penerima dengan menyediakan informasi tersebut

Pada dasarnya secara teori, komunikasi merupakan prasyarat dasar demokrasi. Dalam praktiknya, komunikasi juga tidak terlepas dari bagaimana pemerintah melakukan kegiatannya, mengambil keputusan, membuat kebijakan, membangun hubungan dengan masyarakat, media dan kelompok masyarakat. Selanjutnya, Head (2007:39) mengemukakan bahwa:

“... a primary focus of communications will be information on the availibility of service and benefits, access to services, eligibility for service, changes to such arrangements, and various rights and obligations." Pernyataan di atas menjelaskan bahwa fokus utama komunikasi adalah adanya informasi tentang ketersediaan dan manfaat pelayanan, akses masyarakat ke layanan, hak untuk mendapatkan pelayanan, perubahan pengaturan, dan berbagai hak dan kewajiban. Artinya, dengan jelas pendapat tersebut menyatakan bahwa komunikasi memiliki keterkaitan dengan pelayanan publik. Lebih jauh Spacek \& Spalek (2007:1) mengemukakan bahwa:

Communication within the system of public administration is considered a crucial factor for achieving effective and economical functioning of the whole system of public administration as a specific institutional tool for the implementation of public policies. The quality of information relationships between individual subjects of public administration is determined by a number of factors, and it influences the overall systematic structure of the whole public administration organization. Further, it also affects the quality of information flows carried out within the whole system of public authority of the state, as well as the characteristics of external relationships of public administration.

Mencermati pernyataan di atas, bahwa komunikasi dalam sistem administrasi publik menjadi faktor penting untuk mencapai efektifitas fungsi seluruh sistem administrasi publik, terutama dalam pelaksanaan kebijakan publik. Kualitas hubungan informasi antara subjek individu administrasi publik ditentukan oleh sejumlah faktor, dan hal itu mempengaruhi struktur sistematis keseluruhan administrasi organisasi publik. Pada gilirannya akan mempengaruhi kualitas arus informasi yang dilakukan dalam seluruh sistem otoritas publik negara, serta karakteristik hubungan eksternal administrasi publik. Komunikasi merupakan salah-satu variabel penting yang mempengaruhi implementasi kebijakan publik, komunikasi sangat menentukan keberhasilan pencapaian tujuan dari implementasi kebijakan publik. Implementasi yang efektif akan terlaksana, jika para pembuat keputusan mengetahui mengenai apa yang akan mereka kerjakan. Informasi yang diketahui para pengambil keputusan hanya bisa didapat melalui komunikasi yang baik.

Sejalan dengan pernyataan di atas, Edward III (1980:9-10) mengemukakan bahwa: “... four critical factors or variables in implementing public policy: communication, resources, dispositions or attitudes, and bureaucratic structure." Implementasi kebijakan akan dapat berjalan dengan baik apabila didukung oleh faktor komunikasi, disposisi, sumber daya, dan struktur birokrasi. Faktor komunikasi dalam teori tersebut merupakan faktor yang pertama dan utama dalam menentukan keberhasilan implementasi kebijakan, di samping faktor yang lain. Kebijakan yang dimaksud tentu saja kebijakan publik yang menyangkut tentang apa saja yang dibuat oleh pemerintah, termasuk kebijakan tentang kualitas pelayanan yang dilakukan oleh organisasi pelayanan publik.

Lebih jauh Edwards III (1980:17) mengemukakan bahwa ada tiga indikator yang dapat digunakan dalam mengukur keberhasilan variabel komunikasi, ketiga indikator tersebut adalah:

(1) Transmission. Distribution of good communication will be able to produce a good implementation too. Often there are problems in the distribution of communications that is a misunderstanding (miscommunication) caused many levels of bureaucracy that must be passed in the communication 
Kebijakan: Jurnal Ilmu Administrasi

Volume 10, Nomor 1, Januari 2019

E-ISSN: 2656-2820

P-ISSN 1829-5762

process, so that what is expected to be distorted in the middle of the road. (2) Clarity. Communications received by the policy implementers (street-level-bureaucrats) must be clear and not confusing or ambiguous/ambivalent. (3) Consistency. Commands given in the implementation of a communication should be consistent and clear to set or run. If the command is given frequent changes, it can cause confusion for implementers in the field.

Ketiga indikator tersebut saling berhubungan dan saling mempengaruhi satu sama lain. Sejatinya, penyaluran komunikasi yang baik akan dapat menghasilkan suatu implementasi yang baik pula. Tetapi, implementasi yang baik tidak terlepas dari kejelasan komunikasi yang disampaikan atau diterima oleh pelaksana kebijakan tersebut. Kejelasan informasi dan komunikasi belumlah memadai bila komunikasi tidak konsisten untuk ditetapkan atau dijalankan. Jika perintah yang diberikan sering berubah-ubah, maka dapat menimbulkan kebingungan bagi pelaksana di Berdasarkan uraian di atas, maka dapat dikatakan bahwa faktor komunikasi sangat berpengaruh terhadap penerimaan kebijakan oleh kelompok sasaran, sehingga kualitas komunikasi akan mempengaruhi dalam mencapai efektivitas implementasi kebijakan publik. Dengan demikian, penyebaran isi kebijakan melalui proses komunikasi yang baik akan mempengaruhi keberhasilan implementasi kebijakan. Dalam hal ini, media komunikasi yang digunakan untuk menyebarluaskan isi kebijakan kepada kelompok sasaran akan berperan, termasuk di antaranya adalah kebijakan tentang pelayanan publik. Penjelasan di atas sejalan dengan pendapat Zeithaml dkk (1990:22) yang mengemukakan bahwa - ... komunikasi merupakan salah satu dimensi yang mempengaruhi kualitas pelayanan (SERVQUAL).\| Komunikasi yang dimaksudkan menurut Zeithaml dkk. (1990:26) adalah “...Listens to its customers and acknowledges their comments. Keeps customers informed. In a language which they can understand." Kemauan pemberi pelayanan untuk mendengarkan suara, keinginan atau aspirasi pelanggan, sekaligus kesediaan untuk selalu menyampaikan informasi baru kepada masyarakat. Spacek \& Spalek (2007:3) mengemukakan bahwa:

"...the process of communication plays a very important role in public administration. Every member of an administrative organization needs certain information for making a decision. Characteristics of information flows determine features of the communication within public administration system." Memperhatikan pendapat di atas, dapat digarisbawahi bahwa proses komunikasi memainkan peran yang sangat penting dalam administrasi publik. Setiap anggota organisasi dalam administrasi membutuhkan informasi tertentu untuk membuat keputusan. Karakteristik arus informasi menentukan fitur komunikasi dalam sistem administrasi publik.

\section{Dimensi-dimensi Komunikasi}

Dimensi-dimensi dalam komunikasi tidak terlepas dari dimensi-dimensi yang telah dikemukakan oleh para pakar. Head (2007:39) mengatakan bahwa:

- Government leaders and their public sector managers are vitally interested in all dimentions of communications and marketing. If politics is fundamentally about the art of persuasion, governments are concerned to use all available mechanism of influence. The techniques of marketing can be very powerful in influencing citizens; the challenge for the public interest is to ensure that these techniques are used responsibly." Berbagai dimensi komunikasi dapat dimanfaatkan oleh pemerintahan dalam rangka menyampaikan pesan-pesan pembangunan dan pelayanan guna kepentingan masyarakat umum. Beberapa penelitian tentang komunikasi juga mengadopsi dimensidimensi komunikasi yang telah dijelaskan dan diuraikan oleh para ahli komunikasi. Misalnya, penelitian disertasi yang dilakukan oleh Sunarto tahun 2008 dengan judul disertasi: - Pengaruh Komunikasi dan Motivasi Kerja Aparatur terhadap Kualitas Pelayanan Sertifikat Tanah di Kantor Pertanahan Kotamadya Jakarta Selatan," menggunakan dimensi-dimensi komunikasi yang 
dikemukakan oleh Lasswell. Ndraha (2003:67) berpendapat bahwa komunikasi umumnya menekankan pada dua aspek, yaitu:

—... pertama memberikan tekanan pada proses penyampaian berita berdasarkan teori Lasswell tentang komunikasi (message transmission theory): - Who says in which channel to whom with what effect," sedangkan yang kedua memberikan tekanan pada pertukaran nilai atau proses pertukaran pikiran: "The process of exchange of meaning by verbal and non verval signs operating through cosmologies, cultural, contents, and conduits."

Teori komunikasi yang dianggap paling awal dikembangkan menurut Effendy (2003:253) adalah teori Lasswell. Harold D. Lasswell (1948) dalam tulisannya yang berjudul The Structure and Function of Communication in Society, The Communication of Ideas menyatakan bahwa cara yang terbaik untuk menerangkan proses komunikasi adalah menjawab pertanyaan: Who says in which channel to whom with what effect (Siapa mengatakan apa melalui saluran apa kepada siapa dengan efek apa). Jawaban bagi pertanyaan paradigmatik Lasswell itu merupakan unsur-unsur proses komunikasi yaitu Communicator (strategi komunikator), Message (pesan), Media (media), Receiver (komunikan/penerima), dan Effect (efek/pengaruh). Model komunikasi tersebut dituangkan dalam gambar berikut ini:

Gambar 1.1 Model Komunikasi Lasswell

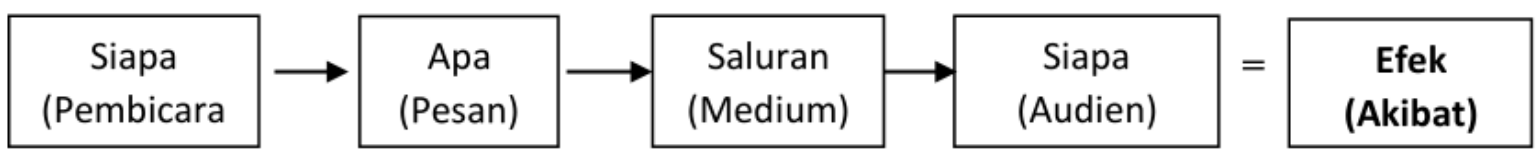

Sumber: Harold D. Laswell (Ruben, 1988)

Sebagaimana dikemukakan oleh Arni Muhammad (2009:5-6), yang dimaksud dengan pertanyaan who tersebut adalah menunjuk kepada siapa orang yang mengambil inisiatif untuk memulai komunikasi. Yang memulai komunikasi ini dapat berupa seseorang dan dapat juga sekelompok orang seperti organisasi atau persatuan. Pertanyaan kedua adalah says what atau apa yang dikatakan. Pertanyaan ini adalah berhubungan dengan isi komunikasi atau apa pesan yang disampaikan dalam komunikasi tersebut. Pertanyaan ketiga adalah to whom. Pertanyaan ini maksudnya menanyakan siapa yang menjadi audience atau penerima dari pesan yang disampaikan. Pertanyaan keempat adalah through what atau melalui media apa. Yang dimaksudkan dengan media adalah alat komunikasi, seperti berbicara, gerakan badan, kontak mata, sentuhan, radio, televisi, surat, buku, gambar, dan sebagainya. Yang perlu diperhatikan dalam hal ini adalah tidak semua media cocok untuk maksud tertentu. Pertanyaan terakhir adalah what effect atau apa efeknya/pengaruhnya dari komunikasi tersebut. Pertanyaan mengenai efek komunikasi ini dapat menanyakan dua hal sekaligus, yaitu apa yang ingin dicapai dengan hasil komunikasi tersebut dan kedua, apa yang dilakukan orang sebagai hasil dari komunikasi. Akan tetapi perlu diingat, bahwa kadang-kadang tingkah laku seseorang tidak hanya disebabkan oleh faktor hasil komunikasi tetapi juga dipengaruhi faktor lain.

Berdasarkan uraian tersebut di atas, ada lima dimensi komunikasi dari Lasswell, yaitu: (1) dimensi strategi komunikator; (2) dimensi pesan; (3) dimensi media; (4) dimensi komunikan; dan (5) dimensi efek. Masing-masing dimensi memiliki karakteristik dan indikator tersendiri sesuai dengan situasi dan kondisi dimana dan kapan komunikasi itu berlangsung atau dilakukan. Dalam strategi komunikator, peran strategi komunikator sebagai penyampai pesan berperan penting. Strategi komunikator yang dilakukan harus luwes sehingga strategi komunikator sebagai pelaksana dapat segera mengadakan perubahan apabila ada suatu faktor yang mempengaruhi. Suatu pengaruh yang menghambat komunikasi bisa datang sewaktu-waktu, lebih lagi jika komunikasi dilangsungkan melalui 


\section{Kebijakan: Jurnal Ilmu Administrasi \\ Volume 10, Nomor 1, Januari 2019 \\ E-ISSN: 2656-2820 \\ P-ISSN 1829-5762}

media massa. Faktor-faktor yang berpengaruh bisa terdapat pada komponen komunikan, sehingga efek yang diharapkan tak kunjung tercapai (Effendy Onong, 2003:304).

Proses pentahapan komunikasi ini mengandung maksud bahwa komunikasi sendaknya dimulai dengan membangkitkan perhatian (attention) sebagai awal suksesnya komunikasi. Apabila perhatian komunikasi telah terbangkitkan, hendaknya disusul dengan upaya menumbuhkan minat (interest), yang merupakan derajat yang lebih tinggi dari perhatian. Minat adalah kelanjutan dari perhatian yang merupakan titik tolak bagi timbulnya hasrat (desire) untuk melakukan suatu kegiatan yang diharapkan strategi komunikator. Hanya ada hasrat saja pada diri komunikan, bagi strategi komunikator belum berarti apa-apa, sebab harus dilanjutkan dengan datangnya keputusan (decision), yakni keputusan untuk melakukan tindakan (action) sebagaimana diharapkan strategi komunikator (Effendy, 2003 : 305). Dimensi komunikasi yang dikemukakan oleh Lasswell terdiri dari lima dimensi, sedangkan komunikasi yang dikemukakan oleh Berlo terdiri dari empat dimensi. Masing-masing dimensi memiliki karaktersitik dan indikator yang berbeda antara satu dengan lainnya.

Uraian tentang komunikasi dan berbagai dimensi dari masing-masing komunikasi tersebut, maka penelitian ini akan menggunakan dimensi-dimensi komunikasi yang dikemukakan oleh Lasswell. Dari sekian banyak teori yang ada, teori Lasswell lebih memungkinkan untuk digunakan dalam penelitian ini, karena lebih relevan dan cocok dengan fenomena dan permasalahan yang diangkat serta dimensi-dimensi komunikasi pada teori Lasswell diharapkan dapat menjelaskan semua seluk-beluk tentang komunikasi secara komprehensif dalam hubungannya dengan kualitas pelayanan PDAM Kota Sukabumi. Sesuai dengan teori Lasswell, bahwa yang bertindak sebagai strategi komunikator dalam pelayanan adalah para aparatur pemerintah daerah di lingkungan PDAM, terutama aparat yang langsung berhadapan dengan masyarakat sedangkan isi pesan (says what) yang disampaikan oleh strategi komunikator adalah berupa prosedur, mekanisme, dan berbagai persyaratan dalam permohonan PDAM, untuk kata-kata to whom adalah masyarakat pemohon PDAM, dan in which channel yaitu melalui saluran agar efek sesuai dengan harapan. Saluran dimaksud dapat dilakukan secara langsung atau melalui media.

Konsep kualitas banyak dibahas dalam studi manajemen. Pengertian atau makna konsep kualitas itu sendiri telah diberikan oleh banyak pakar manajemen dengan berbagai sudut pandang, sehingga menghasilkan definisi-definisi yang beragam, sebagaimana dikemukakan berikut ini. Kualitas (quality) memiliki aneka pengertian, seperti Tjiptono (1996:51) yang mengartikan bahwa:

Konsep kualitas sering dianggap sebagai ukuran relatif kebaikan suatu produk barang atau jasa yang terdiri atas kualitas desain dan kualitas kesesuaian. Kualitas desain merupakan fungsi spesifikasi produk, sedangkan kualitas kesesuaian adalah suatu ukuran seberapa jauh suatu produk rnampu memenuhi persyaratan atau spesifikasi kualitas yang telah ditetapkan. Pada kenyataannya aspek ini bukanlah satu-satunya aspek kualitas. Tjiptono (1996:51) mengemukakan bahwa secara spesifik tidak ada definisi mengenai kualitas pelayanan yang diterima secara universal, namun dari definisi yang ada terdapat beberapa persamaan, yaitu dalam elemen-elemen sebagai berikut:

1. Kualitas meliputi usaha memenuhi atau melebihi harapan pelanggan;

2. Kualitas mencakup produk, jasa, manusia, proses dan lingkungan;

Kualitas merupakan kondisi yang selalu berubah (misalnya apa yang dianggap kurang berkualitas pada masa mendatang). Perwujudan kualitas pelayanan publik, Waworuntu (1997:3-4) mengemukakan bahwa pelayanan masyarakat yang bermutu menuntut adanya upaya dari seluruh pegawai, baik yang bertugas di front office, yaitu mereka yang berhadapan langsung dengan masyarakat dalam menghasilkan pelayanan yang mencerminkan kualitas sikap maupun para pegawai di back office yang menghasilkan pelayanan di belakang layar yang tidak kelihatan oleh masyarakat. Landasan teoritik untuk operasionalisasi variabel kualitas pelayanan publik, telah banyak 


\section{Kebijakan: Jurnal Ilmu Administrasi \\ Volume 10, Nomor 1, Januari 2019 \\ E-ISSN: 2656-2820 \\ P-ISSN 1829-5762}

dikembangkan konstruksi teoritik untuk melakukan pengukuran terhadap konsep itu. Tjiptono (1996:58), misalnya mengemukakan empat unsur penting yang terkandung dalam konsep pelayanan yang berkualitas yaitu "kecepatan, ketepatan, keramahan, dan kenyamanan". Pasuraman, dkk (1996:70) mengemukakan lima dimensi pokok yang menentukan kualitas jasa/ layanan yaitu:

1. Bukti langsung (tangibles), meliputi fasilitas fisik, perlengkapan pegawai dan sarana komunikasi;

2. Keandalan (reability), yakni kemampuan memberikan pelayanan yang dijanjikan dengan segera, akurat dan memuaskan;

3. Daya tanggap (responsiverness), yakni keinginan para staf untuk membantu para pelanggan dan memberikan pelayanan dengan tanggap;

4. Jaminan (assurance), mencakup pengentahuan, kemampuan, kesopanan, dan sifat yang dipercaya, bebas dari bahaya, resiko atau keragu-raguan;

5. Empati (empathy), meliputi kemudahan dalam melakukan hubungan, komunikasi yang baik, perhatian pribadi dan memahami kebutuhan pelanggan.

Berdasarkan penjelasan di atas, maka pengukuran kualitas pelayanan dalam penelitian ini, di dasarkan pada sejumlah kebijakan yang berkaitan dengan pelayanan PDAM Kota Sukabumi, mulai dari tahapan input, proses, output dan outcomes pelayanan, dengan menganalisis beberapa dimensi kualitas pelayanan yang relevan dengan komunikasi sehingga dapat dilakukan pembandingan pelayanan yang diterima masyarakat antara sebelum dan sesudah pemberlakuan model komunikasi efektif. Berbagai ukuran atau dimensi yang telah dikemukakan sebelumnya tentang kualitas pelayanan, kelima dimensi yang dikemukakan oleh Zeithaml telah sesuai dengan topik yang diangkat dalam penelitian ini, yaitu tentang pelayanan PDAM Kota Sukabumi. Kenyataan menunjukkan bahwa pelayanan yang berlangsung selama ini (sebagaimana diuraikan dalam latar belakang) belum optimal, masih banyak masyarakat yang tidak tahu tentang prosedur pelayanan, biaya yang diperlukan, persyaratan yang harus dipenuhi, waktu yang diperlukan untuk pengurusan, dan lain sebagainya.

Berkenaan dengan hal tersebut di atas, dalam rangka memenuhi harapan masyarakat akan pelayanan PDAM Kota Sukabumi yang berkualitas, maka dimensi-dimensi kualitas pelayanan dimaksud secara teoritis dapat dijelaskan sebagai berikut:

1. Tangible (terlihat/berwujud). Indikator yang dapat dikemukakan pada dimensi ini adalah: Penampilan fisik saat melakukan pelayanan, ketersediaan sarana-prasarana, peralatan, kedisiplinan pegawai/personil, kemudahan memperoleh atau melakukan komunikasi dan informasi;

2. Reliability (kehandalan). Indikator yang dapat dikemukakan pada dimensi ini adalah: Kemampuan untuk melaksanakan layanan yang dijanjikan, ketepatan/keakuratan metode pelayanan, kemampuan mengoperasionalkan berbagai peralatan dalam pelayanan, dan kemampuan pegawai dalam memberikan solusi terhadap masalah pelayanan yang dihadapi;

3. Responsiveness (responsif). Indikator dalam dimensi ini adalah: ketanggapan pegawai terhadap berbagai masalah masyarakat dalam pelayanan izin mendirikan bangunan, kecepatan dalam menanggapi permasalahan yang dihadapi, kecepatan dalam memproses pelayanan izin mendirikan bangunan;

4. Assurance. Indikator-indiktor dalam dimensi ini adalah: keterbukaan prosedur pelayanan, kepastian waktu dan biaya pelayanan, pengetahuan dan kesopanan karyawan, dan kemampuan mereka untuk menyampaikan kepercayaan dan keyakinan;

5. Empati. Indikator dalam dimensi ini adalah: perhatian terhadap masalah yang dihadapi masyarakat dalam pelayanan izin mendirikan bangunan, keinginan pegawai untuk mengetahui (adanya perhatian) permasalahan dalam izin mendirikan bangunan. 


\section{Kerangka Pemikiran dan Hipotesis}

Melayani atau juga dilayani adalah merupakan salah satu bentuk proses interaksi dalam kehidupan bermasyarakat. Hal ini dapat terlihat dalam segala macam bentuk layanan publik atau instansi seperti di pemerintahan, swasta, universitas, sekolah, hotel, rumah sakit dan lain-lain. Menurut Saleh, ${ }^{1}$ salah satu aspek yang penting dalam pelaksanaan pelayanan publik adalah kemampuan seorang petugas layanan dalam berinteraksi dan berkomunikasi dengan orang lain. Komunikasi adalah hal yang paling lumrah dilakukan dalam orang memberikan layanan. Nilai baik tidaknya sebuah layanan sering kali dilihat dari bagaimana cara petugas pemberi layanan dalam berkomunikasi dengan pelanggan. Untuk keterampilan komunikasi ini haruslah dimiliki dan dikuasai dengan baik oleh setiap petugas pemberi layanan. Berkomunikasi adalah sebuah cara yang dilakukan manusia untuk mengungkapkan ide, mengekspresikan perasaan dan mencitrakan diri. Cara seseorang berkomunikasi akan menjelaskan tentang bagaimana dia mempersepsi dirinya dan orang lain. Dalam pelaksanaan pelayanan publik, keterampilan berkomunikasi menjadi salah satu aspek penting yang akan mempengaruhi bagaimana efektifitas pelayanan publik yang diberikan serta akan menentukan dan bagaimana mencitrakan masyarakat organisasi sebagai pemberi pelanggan layanan.

Berkomunikasi, haruslah mampu menempatkan manusia pada posisi yang terhormat sebagaimana pula pelayanan publik adalah sebuah ikhtiar untuk memanusiakan manusia. Salah satu tujuan berkomunikasi adalah mempengaruhi orang lain, dan dalam yang dilakukan komukator mempengaruhi orang lain, maka langkah yang paling tepat adalah dengan menggunakan cara yang paling disukai dan diminati oleh orang lain tersebut, yaitu dengan masuk ke dunia mereka dan itulah yang disebut dengan empati sehingga menimbulkan daya tarik dan dapat menempatkan diri (pada saat proses pelayanan) dengan situasi orang lain. Sehubungan dengan berbagai uraian di atas, Zeithaml dkk. (1990:21); Sunarto (2008:172); dan Hadi Buana (2009:236) berkesimpulan bahwa komunikasi merupakan salah satu faktor yang mempengaruhi kualitas pelayanan. Sedangkan menurut Head (2007:39) bahwa:

“...that a primary focus of communications will be information on the availibility of service and benefits, access to services, eligibility for service, changes to such arrangements, and various rights and obligations." Fokus utama komunikasi dari pernyataan di atas adalah adanya informasi tentang ketersediaan manfaat pelayanan, akses masyarakat ke layanan, hak untuk mendapatkan pelayanan, perubahan pengaturan, dan berbagai hak dan kewajiban.

Sejalan dengan pendapat di atas, Muwafik (2010:10) mengemukakan bahwa:

-... komunikasi merupakan kegiatan utama dan terpenting dalam setiap pelaksanaan kegiatan pelayanan publik yang diberikan organisasi pelayanan sehingga mampu memberikan pelayanan yang terbaik dan berkualitas bagi publiknya....

Berdasarkan uraian di atas, maka dapat dikatakan bahwa komunikasi dengan segala dimensinya dapat mempengaruhi kualitas pelayanan publik. Kajian penulis terhadap teori komunikasi dan kualitas pelayanan Air Minum PDAM Kota Sukabumi menggunakan konstruksi pemikiran berdasarkan pendekatan terhadap hubungan antara pemerintah sebagai penyedia layanan dengan masyarakat sebagai penerima layanan. Kerangka pemikiran tertera pada gambar di bawah ini : 


\begin{tabular}{|c|}
\hline $\begin{array}{c}\text { Strategi Strateg } \\
\text { komunikator }\end{array}$ \\
\hline 1. Attention \\
\hline 2. Interest \\
\hline 3. Desire \\
\hline 4. Decision \\
\hline
\end{tabular}

Gambar 2.4. Kerangka Pemikiran

Berdasarkan kerangka pemikiran sebagaimana telah diuraikan di atas, dapat ditarik hipotesis penelitian sebagai berikut: Besarnya pengaruh strategi komunikator terhadap kualitas pelayanan PDAM ditentukan oleh pesan, media, komunikan, dan efek\|

\section{METODE}

Penelitian ini menggunakan desain kuantitatif dengan metode explanatory survey, yakni: menjelaskan dan menganalisis besarnya pengaruh Strategi Komunikator terhadap Kualitas Pelayanan Pelanggan Air Minum PDAM Kota Sukabumi, baik secara parsial maupun secara simultan. Pertimbangan mendasar penelitian ini dilakukan dengan desain kuantitatif, karena: (1) ingin mencari pengaruh antar variabel X dengan variabel Y; (2) Variabel X (strategi komunikator) dan variabel $\mathrm{Y}$ (kualitas pelayanan pelanggan air minum PDAM) dapat diukur secara kuantitatif berdasarkan indikator-indikator dari masing-masing dimensi dengan menggunakan statistik terapan; (3) Mengajukan hipotesis atau jawaban sementara atas pertanyaan penelitian sebagai acuan dalam mengumpulkan data empiris atau verifikasi data di lapangan, sesuai dengan maksud dan tujuan penelitian. Agar keberadaan data penelitian yang diperoleh dapat digunakan sebagai ukuran besaran pengaruh dari setiap variabel penelitian, maka dilakukan pengujian kausalitas dari faktor-faktor strategi komunikator pada variabel bebas $(\mathrm{X})$ terhadap variabel terikat $(\mathrm{Y})$. Oleh karena itulah, maka analisis data yang digunakan adalah analisis regresi linier multiple yang dilanjutkan dengan menggunakan analisis jalur (Path Analysis). Dengan teknik path analysis akan diketahui besaran pengaruh variabel $\mathrm{X}$ terhadap Y baik secara simultan maupun secara parsial.

Selanjutnya, yang menjadi objek (sasaran) penelitian adalah kelompok masyarakat (kepala keluarga) pelanggan air minum PDAM. Sebagai control information, dilakukan konfirmasi/wawancara kepada aparatur PDAM Kota Sukabumi yakni kualitas pelayanan pelanggan air minum bagian hubungan langganan. Adapun yang menjadi populasi dalam penelitian ini adalah PDAM Kota Sukabumi. Sampel yang digunakan dalam penelitian ini adalah 399 responden. Dari jumlah sampel tersebut maka yang akan dialokasikan berdasarkan sebaran setiap wilayah. Peneliti menggunakan skala likert yakni jawaban setiap item instrument yang digunakan dalam skala likert ini mempunyai gradasi dari sangat positif sampai sangat negative. instrumen penelitian diuji melalui validitas dan reliabilitas, menggunakan rumusan korelasi pearson product moment dan reliabilitas instrument dilakukan dengan internal konsistensi dengan teknik belah dua (split half) yang dianalisis dengan menggunakan rumus spearman brown. Koefisien korelasi yang digunakan adalah korelasi pearson product moment Selanjutnya Koefisien determinasi digunakan untuk mengetahui pengaruh antara variabel $\mathrm{X}$ terhadap variabel Y. Pengujian Hipotesis dengan menggunakan Uji keberartian koefisien korelasi dengan rumus uji t. 


\section{PEMBAHASAN}

Hasil analisis pengaruh strategi komunikator terhadap kualitas pelayanan pelanggan air minum PDAM Kota Sukabumi. Pengaruh ini dapat dilihat pada gambar di bawah ini.

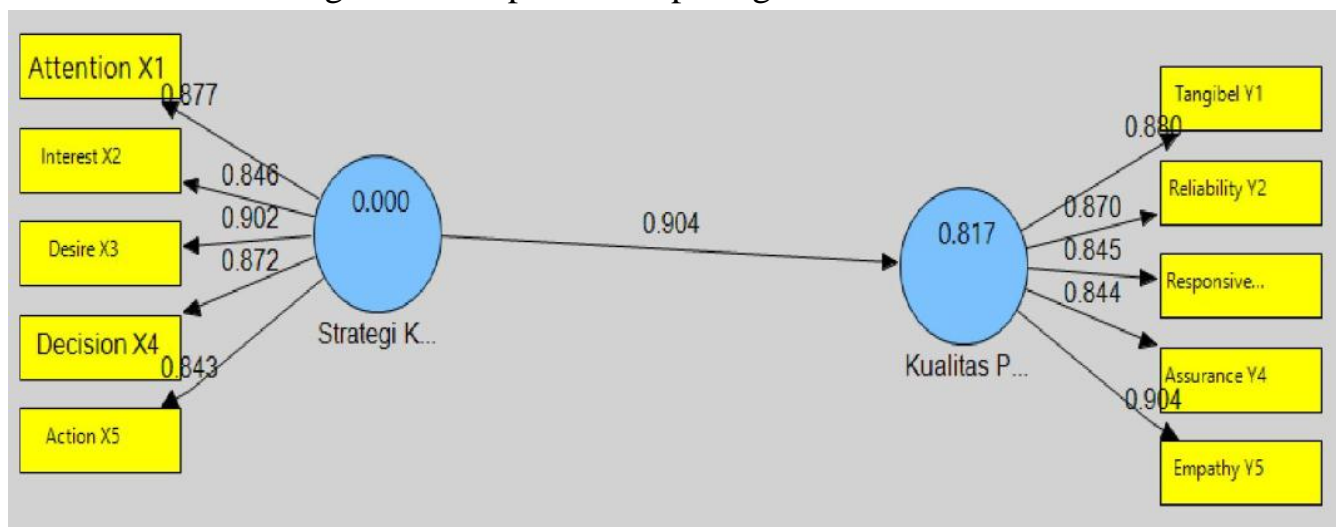

Gambar 4.1 Pengaruh Strategi komunikator Terhadap Kualitas Pelayanan Pelanggan Air Minum PDAM Kota Sukabumi

Berdasarkan gambar 4.1, pengaruh strategi komunikator terhadap kualitas pelayanan sebesar 0,904. Nilai ini positif dan mendekati satu, sehingga dapat disimpulkan pengaruhnya sangat kuat dan arahnya positif. Artinya semakin baik strategi komunikator yang dilakukan, akan kualitas pelayanan yang dirasakan pelanggan akan semakin meningkat. Berdasarkan diagram jalur pada gambar 4.1, dimensi yang paling berkaitan erat atau paling dipentingkan dalam membangun strategi komunikator adalah dimensi Desire, sedangkan dimensi yang paling lemah adalah dimensi Action. Hal ini menunjukkan bahwa desire (hasrat) merupakan elemen penting dalam mewujudkan komunikasi yang efektif dan efisien untuk meningkatkan kualitas pelayanan kepada pelanggan. Pada aspek kualitas pelayanan, dimensi empathy merupakan dimensi yang paling erat kaitannya dengan kualitas pelayanan bagi pelanggan. Hal ini dikarenakan pelanggan lebih menyukai keramahtamahan petugas saat menyelesaikan keluhan pelanggan. Ini berarti semakin baik tatakarama petugas pelayanan, penilaian pelanggan terhadap kualitas pelayanan akan semakin meningkat. Untuk membuktikan ada tidaknya pengaruh yang signifikan dari strategi komunikator terhadap kualitas pelayanan pelanggan air minum PDAM Kota Sukabumi, selanjutnya dilakukan pengujian pengujian hipotesis sebagai berikut.

Ho: $y 21=0 \quad$ Tidak terdapat pengaruh strategi komunikator dalam meningkatkan kualitas pelayanan pelanggan air minum PDAM Kota Sukabumi

Ho: $y 21 * 0 \quad$ Terdapat pengaruh strategi komunikator dalam meningkatkan kualitas pelayanan pelanggan air minum PDAM Kota Sukabumi

Untuk menguji hipotesis ini digunakan statistic uji t pada taraf signifikansi 5\%. Hasil pengujian hipotesis ini dapat dilihat pada table berikut.

Table 4.2 Hasil Uji Hipotesis

\begin{tabular}{|l|l|l|l|l|l|}
\hline $\begin{array}{l}\text { Variabel } \\
\text { Laten }\end{array}$ & $\begin{array}{l}\text { Koefisien jalur Standar } \\
\text { (mean) }\end{array}$ & $\begin{array}{l}\text { T statistic } \\
\text { error }\end{array}$ & T tabel & kesimpulan \\
\hline $\begin{array}{l}\text { Strategi } \\
\text { komunikator }\end{array}$ & 0,904 & 0,009 & 93,422 & 1,984 & Ho ditolak \\
\hline
\end{tabular}

Berdasarkan table 4.2 diketahui bahwa nilai t hitung adalah 93,442. Hal ini lebih besar dari t table 1,984, sehingga Ho ditolak. Dengan demikian dapat disimpulkan bahwa terdapat pengaruh positif dan signifikan dari variable strategi komunikator dalam meningkatkan kualitas pelayanan pelanggan 
Kebijakan: Jurnal Ilmu Administrasi

Volume 10, Nomor 1, Januari 2019

E-ISSN: 2656-2820

P-ISSN 1829-5762

air minum PDAM Kota Sukabumi. Secara rinci, hasil analisis korelasi masing-masing dimensi dapat dilihat pada table 4.3 sebagai berikut.

Table 4.3 Hasil Analisis Korelasi Masing-masing Dimensi

\begin{tabular}{|l|l|l|l|l|l|l|l|l|l|l|}
\hline Dimensi & Attention & interest & desire & decision & action & tangibel & reliability & $\begin{array}{c}\text { Response } \\
\text { veness }\end{array}$ & $\begin{array}{c}\text { assuran } \\
\text { ce }\end{array}$ & $\begin{array}{c}\text { empat } \\
\text { hy }\end{array}$ \\
\hline Attention & 1,000 & - & - & - & - & - & - & - & - & - \\
\hline Interest & 0.729 & 1,000 & 0.727 & 0.632 & 0.635 & - & - & - & 0.597 & 0.754 \\
\hline Desire & 0.768 & - & 1,000 & 0.776 & 0.677 & - & - & - & 0.676 & - \\
\hline Decision & 0.656 & - & - & 1,000 & 0.727 & - & - & - & 0.701 & - \\
\hline Action & 0.690 & - & - & - & 1,000 & - & - & - & - & - \\
\hline Tangible & 0.680 & 0.720 & 0.760 & 0.717 & 0.704 & 1,000 & 0.694 & 0.682 & 0.650 & 0.775 \\
\hline Reliability & 0.682 & 0.608 & 0.763 & 0.720 & 0.674 & - & 1,000 & - & 0.730 & 0.742 \\
\hline $\begin{array}{l}\text { Responsiv } \\
\text { eness }\end{array}$ & 0.645 & 0.602 & 0.678 & 0.684 & 0.620 & & 0.650 & 1,000 & 0.647 & 0.715 \\
\hline Assurance & 0.599 & - & - & - & 0.553 & - & - & - & 1,000 & - \\
\hline Empathy & 0.714 & - & 0.847 & 0.775 & 0.658 & 0.689 & - & - & - & 1,000 \\
\hline
\end{tabular}

Berdasarkan table tersebut, hasil analisis korelasi menunjukkan adanya korelasi yang positif dari masing-masing dimensi dalam variable strategi komunikator dan variable kualitas pelayanan. Hal ini menunjukkan bahwa setiap dimensi dalam variable strategi komunikator dan kualitas pelayanan saling mendukung satu sama lain.

\section{KESIMPULAN}

Berdasarkan rumusan masalah dan hasil analisis data, ditemukan bahwa terdapat pengaruh yang positif dan signifikan dari variable strategi komunikator dalam meningkatkan kualitas pelayanan pelanggan air minum PDAM Kota Sukabumi. Hasil Ini menunjukkan bahwa strategi komunikator memiliki peranan penting dalam meningkatkan kualitas pelayanan bagi pelanggan di PDAM Kota Sukabumi. Pengaruh terbesar yang diberikan oleh strategi komunikator adalah dimensi desire (hasrat). Pelanggan menilai bahwa indikator yang paling diharapkan dilaksanakan dalam pelayanan adalah petugas PDAM memiliki keinginan yang kuat dalam memberikan pelayanan kepada pelanggan. Sehingga kesungguhan memberikan pelayanan inilah yang dapat meningkatkan kualitas pelayanan. Kualitas pelayanan petugas PDAM Kota Sukabumi yang mendapat apresiasi pelanggan paling tinggi adalah dimensi empati, khsusnya dalam upaya petugas mendahulukan kepentingan pelanggan. Berdasarkan hasil penelitian, dimensi desire (hasrat) memberikan nilai tertinggi untuk mencapai efektivitas strategi komunikator yang digunakan dalam meningkatkan kulitas pelayanan pelanggan air minum PDAM Kota Sukabumi. Oleh karena itu, pegawai diharapkan meningkatkan kemampuan dan keahlian dalam bekerja, meningkatkan aspek keinginan yang kuat dalam memberikan pelayanan terbaik, meningkatkan tanggung jawab, etika, sikap profesionalisme, dan kemauan untuk lebih baik dalam memberikan pelayanan kepada pelanggan air minum PDAM Kota Sukabumi.

\section{DAFTAR PUSTAKA}

Budyatna \& Mutmainah. 1994. Komunikasi Antarpribadi. Jakarta: Universitas Terbuka

Dwiyanto, Agus. 2002. Reformasi Tata Pemerintahan dan Otonomi Daerah. Yogyakarta: Pusat Studi Kependudukan dan Kebijakan UGM.

Edward III, George C. 1980. Implementing Public Policy. Washington, D.C.: Congressional Quarterly Press.

Effendy, Onong Uchjana. 2003. Ilmu, Teori dan Filsafat Komunikasi. Bandung: Citra Aditya Bakti. 2006. Hubungan Masyarakat Suatu Studi Komunikologis. Bandung: Remaja Rosdakarya.

2007. Komunikasi Teori dan Praktek. Bandung: Remaja Rosdakarya. 
Kebijakan: Jurnal Ilmu Administrasi

Volume 10, Nomor 1, Januari 2019

E-ISSN: 2656-2820

P-ISSN 1829-5762

Gaspersz, Vincent. 1997. Manajemen Kualitas, Penerapan Konsep-konsep Kualitas Dalam Manajemen Bisnis Total. Jakarta: P.T Gramedia Pustaka Utama.

Head, Brian. 2007. The Public Service and Government Communication: pressures and dilemmas, in Sally Young (Ed.), Government Communication in Australia. Melbourne: Cambridge University Press.

Ingraham, Patricia W, Barbara S. Romzek Associates. 1994. New Paradigms Government. Issues for the Changing Public Service. San Fransisco: Jossey - Bass Publishers.

Kerlinger, Fred N. 2006. Fondation Of Behavioral Research. Penterjemah Landung R Simanjuntak. Yogyakarta: Gajahmada University Press..

Lasswell, Harold D. 1948. The Structure and Function of Communication in Society, in Lyman Bryson (editor). 1948. The Communication of Ideas. New York: Institute for Religious and Social Studies, Jewish Theological Seminary of America.

Maxwell, Joseph A. 1996. Qualitative Research Design An Introduction Approach. London: Sage Publications Thousands Oach.

Muhammad, Arni. 2009. Komunikasi Organisasi. Jakarta: Bumi Aksara.

Moenir, H.A.S. 2008. Manajemen Pelayanan Umum di Indonesia. Jakarta: PT. Bumi Aksara.

Neuman, W. Lawrence. 1997. Social Research Methods, Qualitative and Quantitative Approaches

$\left(3^{\text {rd }}\right.$ ed). Allyn and Bacon a Viacom Company, MA.

Ndraha, Taliziduhu. 2003. Kybernology (Ilmu Pemerintahan Baru) Jilid 1 \& 2. Jakarta: Rineka Cipta

Ratminto \& Atik Septi Winarsih. 2007. Manajemen Pelayanan. Yogyakarta: Pustak Pelajar.

Ruben, Brent D. \& Stewart, Lea P. 2005. Communication and Human Behaviour. USA: Alyn and Bacon.

Špaček, David \& Špalek, Jiř́. 2007. Communication and Electronic Public Administration: Some Issues in the Context of the Czech System of Public Administration. In Lessons and Recommendations for Improvement: Central and Eastern European Public Administration and Public Policy. Bratislava: NISPAcee. ISBN 978 -80-89013 -31-9. 